\title{
Correlation Between Disability Status and Quality of Life in Multiple Sclerosis Female Patients with Urinary Incontinence
}

\author{
(1) Aybüke Ersin, ${ }^{1}$ (1) Merve Alökten, ${ }^{2}$ (D) Fatma Mutluay, ${ }^{3}$ (1) Melih Tütüncü, ${ }^{4}$ \\ (1) Ugur Uygunoglu, ${ }^{4}$ (1) Sabahattin Saip, ${ }^{4}$ (i) Aksel Siva ${ }^{4}$
}

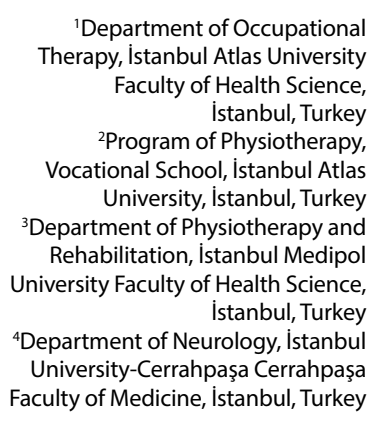

Submitted: 30.11 .2020 Accepted: 09.02.2021

Correspondence: Aybüke Ersin İstanbul Atlas Üniversitesi Sağlık Bilimleri Fakültesi, Ergoterapi Bölümü, İstanbul, Turkey

E-mail: aybuke.ersin@atlas.edu.tr

arist

Keywords: Disability status; multiple sclerosis; quality of life; urinary incontinence.

\begin{abstract}
Objective: Multiple sclerosis (MS) is a progressive, inflammatory, chronic, and neurodegenerative disease. One of the most common symptoms of MS patients is urinary incontinence with high rates of up to $90 \%$. The previous studies have shown that urinary incontinence reduces the quality of life of MS patients. However, it is not known whether there is a relationship between the Expanded Disability Status Scale (EDSS) scores, which determine the physical disability level of MS, and the quality of life scores caused by urinary problems. For this reason, our study focuses on the relationship between EDSS scores and King's Health Questionnaire (KHQ) scores, which is one of the quality of life questionnaires specific to urinary incontinence.
\end{abstract}

\begin{abstract}
Methods: The study included 32 female patients aged 18-65 years, diagnosed with MS, and received outpatient treatment at the Neurology Clinic of Cerrahpaşa School of Medicine Hospital. There was no categorization among the patients' EDSS scores. Quality of life associated with urinary incontinence was measured with the KHQ. Normal distribution was assessed by Kolmogorov-Smirnov test and non-parametric correlation was calculated by Spearman's rho coefficients using SPSS version 22.
\end{abstract}

Results: It was found a statistically significant negative correlation between urinary incontinence-related quality of life and disability status $(r=0.392, p<0.05)$.

Conclusion: In our study, we found that MS patients with high EDSS scores have low urinary continence-related quality of life scores.

\section{INTRODUCTION}

Multiple sclerosis (MS) is a chronic, inflammatory, progressive, degenerative neurological disease that affects the central nervous system. ${ }^{[]}$Patients with MS commonly experience fatigue, ataxia, tremor, spasticity, urinary system and bowel dysfunction, visual impairment, pain, cognitive disorders, dysphagia, and sexual dysfunction. ${ }^{[2,3]}$ Among these symptoms, lower urinary tract dysfunction is a common problem affecting $50-90 \%$ of patients with MS. ${ }^{[4]}$

Brain imaging studies have determined that high cortical regions and various signal processing pathways are involved in bladder control. Storage and voiding function become socially available at the appropriate time and place while under the control of high cortical areas. ${ }^{[5]}$ Voluntary voiding is ordered from these high cortical regions such as thalamus and prefrontal cortex, and voiding occurs with the activation of the parasympathetic system through the activation of the pontine micturition center (PMC), which is a subcortical structure. Conversely, if the PMC is inhibited, the storage function occurs. ${ }^{[5,6]}$ In MS disease, it is accepted that urinary problems occur due to the dysfunction of these pathways due to the disease-specific degenerations observed in the central nervous system structures. ${ }^{[7]}$

Lower urinary tract symptoms (LUTSs) are divided into three categories; storage, voiding, and post-micturition. 
Urinary leakage and urge incontinence, which are among the symptoms of voiding, are frequently observed in patients with MS. ${ }^{[4,8]}$

In Turkey, the incontinence observed in the population without MS disease ranges from $20 \%$ to $25 \%$. $^{[9]}$ On the other hand, although there are no data on the frequency of incontinence in individuals with MS in our country, it has been reported that the incidence of urinary incontinence in individuals with $\mathrm{MS}$ is $75 \%$ in international studies. ${ }^{[10]}$ The observed urinary incontinence also correlates with the Expanded Disability Status Scale (EDSS) scores, which reveal the patient's physical disability, and it has been shown that MS patients with high EDSS scores may be more affected by LUTS. ${ }^{[1]}$

Urinary incontinence, which is observed at a high rate in individuals with MS and correlates with physical disability, reduces people's adaptation to social life and their quality of life (QoL). ${ }^{[12,13]}$ Some previous studies have evaluated health-related QoL (HR-QoL) when measuring the relationship between LUTS and QoL in MS patients. ${ }^{[14]}$ On the other hand, QoL assessment studies for urinary incontinence are mostly applied to the general population. Despite this, the effects of QoL caused by urinary problems can be measured with the evaluation tools developed by researchers regarding specific problems seen in multisystemic diseases such as MS. ${ }^{[15,16]}$ One of these specific questionnaires for urinary incontinence is King's Health Questionnaire (KHQ) developed by clinicians of King's College Urogynecology Department. ${ }^{[17]}$ The KHQ is a comprehensive questionnaire about how urinary incontinence affects oneself and daily life. In addition, most of the studies focused on urinary incontinence and QoL, but there were no studies that showed relationship between EDSS scores and urinary incontinence-related QoL.

In the light of this information, our study aims to investigate the correlation between QoL values affected by urinary incontinence and disability scores in patients with MS.

\section{MATERIALS AND METHODS}

Fifty-seven women between the ages of 18 and 65 who were diagnosed with $\mathrm{MS}$ and received outpatient treatment at the Neurology Clinic between April 2018 and September 2018 were included in the study. Male gender and participants who diagnose with diabetes mellitus are excluded. Furthermore, 25 out of 57 patients were excluded because they had complaints but have not diagnosed urinary incontinence by physician and physiotherapist after urinary examination and assessments.

The investigation was conducted in one individual session in which the participant's demographic data were recorded on a chart. Participants have lower urinary tract symptom or symptoms (overactive bladder syndrome, stress incontinence, urgency/urge incontinence, mixed type incontinence, and neurogenic bladder syndrome). Two participants have stress incontinence, 18 participants have urge urinary incontinence, eight participants have mixed urinary incontinence, and four participants have insensible urinary incontinence.

Totally, the study included 32 female patients aged 18-65 years diagnosed as MS, with any EDSS score, who were receiving regular medical care at the neurology clinic.

QoL was assessed by QoL specific to urinary incontinence $\mathrm{KHQ}$. The KHQ is a disease-specific HR-QoL instrument to measure HR-QoL of patients with urinary incontinence.

[17] Since its development, the KHQ has been widely used in clinical studies as a valid, reliable, and clinically sensitive endpoint. ${ }^{[18]}$ The validity and reliability study of the Turkish version of the KHQ has been done. ${ }^{[19]}$ Furthermore, Akkoc et al. ${ }^{[20]}$ studied the validity and reliability of Turkish version of $\mathrm{KHQ}$ in $\mathrm{MS}$ patients with urinary incontinence specifically.

Patients' disability status scored with EDSS. The EDSS is the most used rating system to determine the severity and progression of MS. EDSS is based on functional systems as follows: Pyramidal, cerebellar, brainstem, sensory, sphincters, visual, mental, and other. The EDSS score ranges from 0 to 10 , higher scores meaning more disability. ${ }^{[1]}$

The study has been approved by the Non-Interventional Clinical Research Ethics Committee (10840098604.01.01-E.10249). All participants signed an informed consent form.

\section{Statistical analysis}

All data analyses were made using the SPSS version 22 . Normal distribution was assessed by Kolmogorov-Smirnov test. Spearman's rho nonparametric correlation coefficients between parameters were calculated. The statistical significance level was accepted as $p \leq 0.05$.

\section{RESULTS}

The age of participants is ranged from 20 to 65 years $(44.93 \pm 10.78)$. The time elapsed after diagnosing MS var-

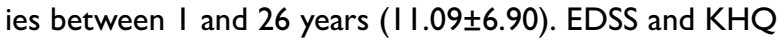
scores are shown in Table $\mathrm{I}$.

It was found a statistically significant negative correlation between urinary incontinence-related QoL and disability status $(r=0.392, p<0.05)$. There was no correlation between the QoL associated with urinary incontinence and the year and age of the disease $(r=-0.274, p>0.05$; $r=-0.105, p>0.05$ ) (Table 2).

Table I. Sociodemographic attributes

\begin{tabular}{lc}
\hline Characterictics & Mean \pm SD \\
\hline Age (years) & $44.93 \pm 10.78$ \\
MS disease year (years) & $11.09 \pm 6.90$ \\
EDSS Score & $4.28 \pm 1.83$ \\
KHQ Score & $412.20 \pm 201.64$ \\
\hline
\end{tabular}

MS: Multiple sclerosis; EDSS: Expanded Disability Status Scale; KHQ: King's Health Questionnaire; SD: Standart deviation. 
Table 2. Correlations between EDSS and KHQ Scores

\begin{tabular}{clcc}
\hline \multicolumn{3}{c}{ Correlations } \\
\hline & & EDSS & KHQ \\
\hline Spearman's rho & & & \\
EDSS & Correlation Coefficient & 1.000 & $.392^{*}$ \\
& Sig. (2-tailed) &. & .027 \\
KHQ & $\mathrm{N}$ & 32 & 32 \\
& Correlation Coefficient & $392^{*}$ & 1.000 \\
& Sig. (2-tailed) & .027 &. \\
& $\mathrm{~N}$ & 32 & 32 \\
\hline
\end{tabular}

*Correlation is significant at the 0.05 level (2-tailed). Bold values are statistically significant ( $p>0.05$ ). EDSS: Expanded Disability Status Scale, KHQ: King's Health Questionnaire.

\section{DISCUSSION}

In line with the data shown in the literature, $56.14 \%$ of our participants (36 out of 57) had urinary incontinence. [4] Our results are consistent with our hypothesis; there is a significant negative correlation between EDSS scores and impaired QoL due to urinary incontinence, but is not affected by the year of illness and the age of the patient.

There are some studies that show a relationship between symptoms seen in MS patients and EDSS scores. Carvalho et al. ${ }^{[22]}$ determined that there is a correlation between higher EDSS scores and temporomandibular dysfunction in their study. Furthermore, Nazari et al. showed in their study that MS patients with high EDSS scores increase the risk of developing urinary system problems. ${ }^{[I]}$ Besides, although there are studies investigating the relationship between QoL and LUTS in recent literature, there is just one study that showed the relationship between EDSS scores describing physical disability, changing QoL, and increasing depression level due to LUTS. Tudor et al. ${ }^{[23]}$ indicated that LUTSs and EDSS scores are positively correlated and QoL due to LUTSs and depression is positively correlated. Consistent with this recent study, as shown in our study, as the EDSS scores increase, the QoL associated with urinary incontinence decreases.

Unfortunately, a radical treatment for progressive and degenerative MS disease has yet to be found. Treatment of patients' multisystemic symptoms is important for the patient to continue his/her life in a quality way.

One of the important multisystemic symptoms of MS is urinary dysfunction. Although urinary voiding problems are more common in MS patients, ${ }^{[24]}$ storage problems are also observed in MS patients. In both types, the final clinical presentation of these problems is urinary incontinence that seriously affects the daily life of the patients. Physiotherapy interventions were found to be effective in the treatment of urinary incontinence seen in patients with MS and in increasing the QoL by an evidence-based review. ${ }^{[12]}$
In a case study, De Abreu Pereira et al. ${ }^{[25]}$ applied functional vaginal electrical stimulation, tibial nerve stimulation, behavioral rehabilitation, and home exercise program for 15 sessions, I day a week, to a 55-year-old female patient with mixed urinary incontinence. At the end of I 5 weeks, a statistically significant improvement in both urinary incontinence symptoms and QoL of the patient was demonstrated.

In some studies, it has been shown that the application of intravaginal and tibial electrical stimulation in addition to pelvic floor muscle exercises applied for the treatment of overactive bladder syndrome strengthens the pelvic floor muscles and reduces incontinence complaints. ${ }^{[26,27]}$ In addition, the EMG biofeedback method applied with the pelvic floor muscle training program significantly reduces the symptoms of the urinary system and improves the deteriorated QoL caused by urinary symptoms. ${ }^{[28]}$

All these studies have shown that people's urinary problems can be reduced by physiotherapy and rehabilitation methods, since it is not yet possible to stop the progression of the disease due to the progressive degenerative nature of MS. Without waiting for a progressive increase in EDSS scores, early physiotherapy treatment methods can delay the emergence of urinary problems in patients and keep patients' QoL at acceptable levels for the patient.

Future studies may focus on the effect of improved QoL after physiotherapy program on EDSS scores. Thus, it may enable the effect of urinary dysfunction, which is a multisystemic symptom, on physical disability to be measured through QoL.

Our study has some limitations. In our study, we have not a large number of patients. If we had a greater number of patients, we would have stronger statistical results. We're aiming to continue our work by increasing the number of participants. Furthermore, age of participants is not shown as a homogeneous distribution. Age has significant value in case of evaluating urinary symptoms, but we have various ranges of age. This is a limitation of this study, as well.

\section{CONCLUSION}

There is a negative correlation between the EDSS scores of MS patients and their QoL values. Therefore, after diagnosis MS, patients should be evaluated according to LUTS and managed strategies, urinary incontinence should be used instantly.

\section{Ethics Committee Approval}

This study approved by the İstanbul Medipol University Non-Interventional Clinical Research Ethics Committee (Date: 28.03.2018, Decision No: 209).

Peer-review

Internally peer-reviewed.

Authorship Contributions

Concept: A.E., M.A., F.M., M.T., U.U., S.S., A.S.; Design: 
A.E., M.A., F.M., M.T., U.U., S.S., A.S.; Supervision: A.E., M.A., F.M., M.T., U.U., S.S., A.S.; Fundings: A.E.; Materials: M.T., S.S.; Data: M.T., U.U., A.S.; Analysis: F.M., A.E., M.A.; Literature search: A.E., M.A.; Writing: A.E., M.A.; Critical revision: A.E., M.A., F.M., M.T., U.U., S.S., A.S.

\section{Conflict of Interest}

None declared.

\section{REFERENCES}

1. Compston A, McDonald I, Noseworthy J, Lassmann H, Miller D, Smith K, et al. The story of multiple sclerosis. In: McAlpine's Multiple Sclerosis. 4th ed. United Kingdom: Churchill Livingstone, Elsevier Inc; 2006. p. 3-68.

2. Coote $\mathrm{S}$, Hogan N, Franklin S. Falls in people with multiple sclerosis who use a walking aid: Prevalence, factors, and effect of strength and balance interventions. Arch Phys Med Rehabil 2013;94:616-21.

3. Nicholas R, Rashid W. Multiple sclerosis. Am Fam Physician 201;8:712-4.

4. Massot C, Khenioui H, Agnani O, Guyot MA, Hautecoeur P, Donze C. Stress urinary incontinence in women with multiple sclerosis. Int Neurourol J 2016;20:224-31.

5. Kalsi V, Fowler CJ. Therapy insight: Bladder dysfunction associated with multiple sclerosis. at Clin Pract Urol 2005;2:492-501.

6. Tekin A, Bölge Ç, Hastanesi E, Kliniği ÇÜ. İşeme fizyolojisi ve işemenin nöral kontrolü. Çocuk Cerrahisi Derg 2016;30:545-9.

7. Aharony SM, Lam O, Corcos J. Treatment of lower urinary tract symptoms in multiple sclerosis patients: Review of the literature and current guidelines. Can Urol Assoc J 2017;11:E110-5.

8. Khan F, Turner-Stokes L, Ng L, Kilpatrick T. Multidisciplinary rehabilitation for adults with multiple sclerosis. Cochrane Database Syst Rev 2007;2:CD006036.

9. Öztürk GZ, Toprak D, Basa E. 35 yaş üzeri kadınlarda üriner inkontinans sıklı̆ı ve etkileyen faktörlerin değerlendirilmesi. Sisli Etfal Hastan Tip Bul 2012;46:170-6.

10. Panicker J, Haslam C. Lower urinary tract dysfunction in MS: Management in the community. Br J Community Nurs 2009;14:474-80.

11. Nazari F, Shaygannejad V, Sichani MM, Mansourian M, Hajhashemi $\mathrm{V}$. The prevalence of lower urinary tract symptoms based on individual and clinical parameters in patients with multiple sclerosis. BMC Neurol 2020;20:24.

12. Block V, Rivera M, Melnick M, Allen DD. Do physical therapy interventions affect urinary incontinence and quality of life in people with multiple sclerosis? Int J MS Care 2015;17:172-80.

13. Zecca C, Riccitelli GC, Disanto G, Singh A, Digesu GA, Panicari L, et al. Urinary incontinence in multiple sclerosis: Prevalence, severity and impact on patients' quality of life. Eur J Neurol 2016;23:122834.

14. Khalaf KM, Coyne KS, Globe DR, Malone DC, Armstrong EP, Patel $\mathrm{V}$, et al. The impact of lower urinary tract symptoms on health-related quality of life among patients with multiple sclerosis. Neurourol Urodyn 2016;35:48-54.
15. Bonniaud V, Parratte B, Amarenco G, Jackowski D, Didier JP, Guyatt G. Measuring quality of life in multiple sclerosis patients with urinary disorders using the qualiveen questionnaire. Arch Phys Med Rehabil 2004;85:1317-23.

16. Patel DP, Myers JB, Lenherr SM. How to measure quality-of-life concerns in patients with neurogenic lower urinary tract dysfunction. Urol Clin North Am 2017;44:345-53.

17. Kelleher CJ, Cardozo LD, Khullar V, Salvatore S. A new questionnaire to assess the quality of life of urinary incontinent women. Br J Obstet Gynaecol 1997;104:1374-9.

18. Reese PR, Pleil AM, Okano GJ, Kelleher CJ. Multinational study of reliability and validity of the King's health questionnaire in patients with overactive bladder. Qual Life Res 2003;12:427-42.

19. Kaya S, Akbayrak T, Toprak Çelenay Ş, Dolgun A, Ekici G, et al. Reliability and validity of the Turkish King's health questionnaire in women with urinary incontinence. Int Urogynecol J Pelvic Floor Dysfunct 2015;26:1853-9.

20. Akkoc Y, Karapolat H, Eyigor S, Yesil H, Yüceyar N. Quality of life in multiple sclerosis patients with urinary disorders: Reliability and validity of the Turkish version of King's health questionnaire. Neurol Sci 2011;32:417-21.

21. Kurtzke JF. Rating neurologic impairment in multiple sclerosis: An expanded disability status scale (EDSS). Neurology 1983;33:144452.

22. Carvalho LS, Nascimento OJ, Rodrigues LL, Matta AP. Relationship between expanded disability status scale scores and the presence of temporomandibular disorders in patients with multiple sclerosis. Eur J Dent 2018;12:144-8.

23. Tudor KI, Bošnjak Pašić M, Nađ Škegro S, Bakula M, Nemir J, Mustač $\mathrm{F}$, et al. Lower urinary tract symptoms and depression in patients with multiple sclerosis. Psychiatr Danub 2020;32 Suppl 4:511-9.

24. de Almeida CR, Carneiro K, Fiorelli R, Orsini M, Alvarenga RM. Urinary dysfunction in women with multiple sclerosis: Analysis of 61 patients from Rio de Janeiro, Brazil. Neurol Int 2013;5:79-83.

25. De Abreu Pereira CM, Castiglione M, Kasawara KT. Effects of physiotherapy treatment for urinary incontinence in patient with multiple sclerosis. J Phys Ther Sci 2017;29:1259-63.

26. Ferreira AP, Pegorare AB, Salgado PR, Casafus FS, Christofoletti G. Impact of a pelvic floor training program among women with multiple sclerosis: A controlled clinical trial. Am J Phys Med Rehabil 2016;95:1-8.

27. Lúcio A, D’Ancona CA, Perissinotto MC, McLean L, Damasceno BP, De Moraes Lopes MH. Pelvic floor muscle training with and without electrical stimulation in the treatment of lower urinary tract symptoms in women with multiple sclerosis. J Wound Ostomy Continence Nurs 2016;43:414-9.

28. McClurg D, Ashe RG, Lowe-Strong AS. Neuromuscular electrical stimulation and the treatment of lower urinary tract dysfunction in multiple sclerosis-a double blind, placebo controlled, randomised clinical trial. Neurourol Urodyn 2008;27:231-7. 


\section{Üriner İnkontinanslı Kadın Multipl Skleroz Hastalarında Özürlülük Durumu ile Yaşam Kalitesi Arasındaki Iliş̧ki}

Amaç: Multipl skleroz (MS) ilerleyici, enflamatuvar, kronik ve nörodejeneratif bir hastalıktır. MS hastalarının en yaygın semptomlarından biri, \%90'a varan yüksek oranlarla idrar kaçırmadır. Önceki çalışmalar, idrar kaçırmanın MS hastalarının yaşam kalitesini düşürdüğünü göstermiştir. Ancak MS' in fiziksel özür düzeyini belirleyen Genişletilmiş Özürlülük Durum Ölçeği (EDSS) skoru ile üriner sistem sorunlarından kaynaklanan yaşam kalitesi puanları arasında bir ilişki olup olmadığı bilinmemektedir. Bu nedenle çalışmamız, üriner inkontinansa özgü yaşam kalitesi anketlerinden biri olan King Sağlık Anketi (KHQ) puanı ile EDSS skoru arasındaki ilişkiye odaklanmaktadır.

Gereç ve Yöntem: Çalışmaya Cerrahpaşa Tıp Fakültesi Hastanesi Nöroloji Kliniği'nde MS tanısı almış ve ayakta tedavi gören I8-65 yaş arası 32 kadın hasta dahil edildi. Hastaların EDSS skorları arasında herhangi bir sınıflama yoktu. İdrar kaçırma ile ilişkili yaşam kalitesi değerlendirmesi için KHQ kullanıldı. İstatistiksel analiz için SPSS sürüm 22 kullanıldı. Normal dağııım Kolmogorov Smirnov testi ile değerlendirildi, parametrik olmayan korelasyon Spearman'ın rho katsayısı ile hesaplandı.

Bulgular: Üriner inkontinansa özgü yaşam kalitesi ile özürlülük durumu arasında istatistiksel olarak anlamlı negatif bir ilişki bulundu ( $r=0.392$, $\mathrm{p}<0.05)$.

Sonuç: Çalışmamızda EDSS skoru yüksek MS hastalarının üriner inkontinansa özgü yaşam kalitesi skorlarının düşük olduğu ortaya konmuştur.

Anahtar Sözcükler: Multipl skleroz; özürlülük durumu; üriner inkontinans; yaşam kalitesi. 